\title{
ДИЗАЙН АНТИМИКРОБНЫХ АГЕНТОВ НА ОСНОВЕ СМЕШАННЫХ МЕТАЛЛОКОМПЛЕКСОВ (ПОЛИФТОР)САЛИЦИЛОВЫХ КИСЛОТ И ЛИГАНДОВ БИПИРИДИНОВОГО ТИПА
}

\author{
Е.В. Щегольков ${ }^{1}$, И.В. Щур ${ }^{1}$, Я.В. Бургарт ${ }^{1}$, Д.С. Копчук ${ }^{1,2}$, \\ Г.В. Зырянов ${ }^{1,2}$, В.И. Салоутин ${ }^{1}$ \\ ${ }^{1}$ Институт органического синтеза им. И.Я. Постовского УрО РАН, \\ 620108, Россия, г. Екатеринбург, ул. Софьи Ковалевской, 22. \\ 2 Уральский федеральный университет имени первого Президента России \\ Б.Н. Ельцина, 620002, Россия, г. Екатеринбург, ул. Мира, 18.
}

DOI: 10.19163/MedChemRussia2021-2021-122

E-mail:schegolkov@ios.uran.ru

Создание новых антибактериальных и противогрибковых средств, способных к уничтожению устойчивых форм бактерий и грибов, является перспективной и актуальной задачей. При этом в литературе имеются сведения об антимикробной активности металлокомплексов смешанного типа с лигандами бипиридинового типа и с салициловой кислотой. В данной работе, на основе солей металлов $\left(\mathrm{Cu}^{2+}, \mathrm{Co}^{2+}, \mathrm{Mn}^{2+}\right)$ (полифтор)салициловых кислот 1 и (не)замещенного 2,2'-бипиридина или 1,10-фенантролина синтезирован широкий ряд комплексов 2 и 3. Строение синтезированных комплексов подтверждено методом элементного анализа, ВЭЖХ и РСА.
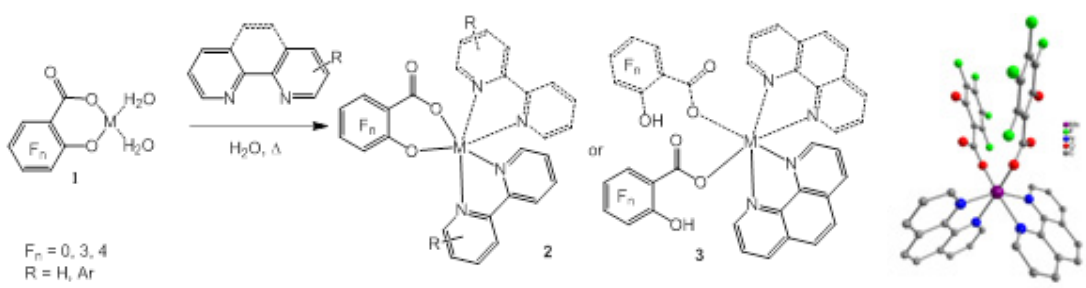

Проведено исследование антимикотической и антибактериальной активности синтезированных гетеролигандных комплексов 2 и 3 в отношении широкого спектра патогенных дерматофитов и дрожжеподобных микроорганизмов и против серии клинически значимых облигатных и условно-патогенных бактерий. Установлено, что ряд соединений обладает анти-гонококковой активностью (МИК 1.9...3.9 мкг/мл), а также антибактериальной активностью в отношении S. aureus, S. aureus MRSA (МИК 1.9...7.8 мкг/Мл) на уровне или выше препарата сравнения спектиномицин. Обнаружено также, что металлокомплексы обладают высоким антимикотическим действием против 6 штаммов грибов рода Trichophyton (МИК 0.19...3.12 мкг/мл), превышающим действие препарата флуканозола.

Работа выполнена при финансовой поддержке Министерства науки и высшего образования Российской Федерации (договор № 075-15-2020-777). 